\title{
What is the Molecular Basis of Nonhost Resistance?
}

\author{
Ralph Panstruga ${ }^{1,+}$ and Matthew J. Moscou ${ }^{2}$ \\ ${ }^{1}$ RWTH Aachen University, Institute for Biology I, Unit of Plant Molecular Cell Biology, Worringer Weg 1, 52056 Aachen, \\ Germany \\ ${ }^{2}$ The Sainsbury Laboratory, University of East Anglia, Norwich Research Park, Norwich, NR4 7UK, United Kingdom
}

Accepted 17 August 2020.

Nonhost resistance is typically considered the ability of a plant species to repel all attempts of a pathogen species to colonize it and reproduce on it. Based on this common definition, nonhost resistance is presumed to be very durable and, thus, of great interest for its potential use in agriculture. Despite considerable research efforts, the molecular basis of this type of plant immunity remains nebulous. We here stress the fact that "nonhost resistance" is a phenomenological rather than a mechanistic concept that comprises more facets than typically considered. We further argue that nonhost resistance essentially relies on the very same genes and pathways as other types of plant immunity, of which some may act as bottlenecks for particular pathogens on a given plant species or under certain conditions. Thus, in our view, the frequently used term "nonhost genes" is misleading and should be avoided. Depending on the plant-pathogen combination, nonhost resistance may involve the recognition of pathogen effectors by host immune sensor proteins, which might give rise to host shifts or host range expansions due to evolutionary-conditioned gains and losses in respective armories. Thus, the extent of nonhost resistance also defines pathogen host ranges. In some instances, immune-related genes can be transferred across plant species to boost defense, resulting in augmented disease resistance. We discuss future routes for deepening our understanding of nonhost resistance and argue that the confusing term "nonhost resistance" should be used more cautiously in the light of a holistic view of plant immunity.

Keywords: effector protein, host jump, NB-LRR protein, nonadapted pathogens, nonhost resistance, pathogen host range, plant responses to pathogens

It is our day-to-day experience that most plants in nature and agriculture look healthy while only few give the impression of suffering from disease. Thus, it appears as if plants, like other organisms, are able to effectively withstand the attacks of most potential pathogenic agents. This phenomenon in phytopathology is referred to as "nonhost resistance" (NHR) - a term that, according to Web of Science, was

${ }^{\dagger}$ Corresponding author: R. Panstruga; panstruga@bio1.rwth-aachen.de

Funding: The work presented in this article is supported by Novo Nordisk Foundation grant NNF19OC0056457 (to R. Panstsruga) and the Gatsby Charitable Foundation (to M. J. Moscou).

The author(s) declare no conflict of interest.

() 2020 The American Phytopathological Society introduced by Michèle Heath to scientific literature in the late 1970s (Heath 1977). NHR is considered a broadly acting and durable type of disease resistance. It is the apparently longlasting invulnerability of most plants to most wannabe pathogens that has sparked a common interest in this subject, not least due to its potential application in crop protection. Despite substantial progress in deciphering the molecular mechanisms underlying NHR, several aspects of this type of disease resistance remain nebulous and poorly comprehended, even within the community of molecular phytopathologists. Thus, it is not a big surprise that the question "What is the molecular basis of NHR?" has been nominated as one of the top 10 unanswered questions in the area of molecular plant-microbe interactions at the recent 18th IS-MPMI congress in Glasgow (Scotland, U.K.). Here, we condense current knowledge about NHR by, in turn, addressing 10 key questions (Q1 to Q10) related to this hot topic. We hope that our answers will help to lift the veil that still oftentimes shrouds this field of plant immunity.

\section{Q1: WHAT IS NHR?}

NHR has been commonly defined as "the ability of all genotypes of a plant species to confer resistance to all genotypes of a pathogen species", where "resistance" often refers to the inability of a pathogen to complete its asexual or sexual life cycle on that plant species (Heath 2000; Lee et al. 2016; Niks and Marcel 2009; Nürnberger and Lipka 2005). We wish to explicitly stress, right at the beginning, the fact that this definition is strictly phenomenological and does not imply a particular molecular mechanism, which are often confused, especially by newcomers to the field. As we will discuss in detail below (see Q5 and Q6), the structural features and molecular processes underlying NHR are multifaceted and depend on the particular plant-pathogen constellation and sometimes even on specific conditions; thus, the term NHR should solely be used in a descriptive and not in a mechanistic sense. Moreover, the familiar definition given above is rather simplistic and bears a number of potential shortcomings. First, it is easily conceivable that it is virtually impossible to test all existing genetic variants of a given plant species against all existing genotypes of a pathogen species. As such, the definition can only be a rough approximation, as judged from common experience or more or less systematic studies on a limited number of samples. Second, traditionally, the definition assumes black-and-white scenarios, with "resistance" and "susceptibility" being the only possible conditions. As such, the term NHR is often linked to the presence or absence of macroscopically visible disease symptoms (e.g., fungal pustules or leaf spots). However, interactions between plants and pathogens often show a gradual behavior, with all kinds of intermediate outcomes 
possible, including the cryptic (only microscopically or molecularly detectable) completion of a pathogen's life cycle. Accordingly, in extension of the original principle, additional terms such as "marginal/near/intermediate host", "near/intermediate nonhost", or "apparent NHR" have been introduced recently to the literature (Ayliffe and Sørensen 2019; Baruah et al. 2020; Bettgenhaeuser et al. 2014; Niks and Marcel 2009) (Fig. 1). The occurrence of microbial species that can act as pathogens on some plant species but live as asymptomatic endophytes on others (e.g., Verticillium dahlia) (Wheeler et al. 2019) further confounds the situation. Third, the definition is only true for a given point in time. A plant species that is nonhost to a particular pathogen species today may have been a host species within their short- or long-term evolutionary history, or it may become a host species in the (near) future. The phenomena of "host range extensions" and "host jumps" are well known in phytopathology, because there are several striking past and contemporary examples (Morris and Moury 2019; Navaud et al. 2018; Thines 2019) (see also Q3 below). Fourth, "completion of the life cycle" is a poor criterion on which to categorize the pathogenic success of some intruders (e.g., bacteria and herbivorous insects). To better define NHR in the context of such organisms, new classifications are necessary (e.g., the efficiency of reproductive success). Fifth, the current definition neglects the fact that NHR can be conditional (e.g., depending on environmental conditions or plant age), organ or tissue specific, or only effective against particular developmental stages of a pathogen (see Q4 below). Taken together, the concept of NHR implies many more facets and features than are often considered (Fig. 1). We will attempt in the following to elaborate in detail on a few of them.

\section{Q2: HOW CAN NHR BE INTEGRATED INTO THE CURRENT MOLECULAR CONCEPTS OF PLANT IMMUNITY?}

As already emphasized above (Q1), NHR is a descriptive and not a mechanistic concept. It differentiates the pathogenic species that can successfully colonize or reproduce on a given plant species from those that fail to do so. It is generally accepted that hosts coevolve with their adapted pathogens, typically resulting in pathogen specialization to one or a few host species (the host range) (Brown and Tellier 2011; Burdon and Thrall 2009; Morris and Moury 2019). In its extreme form, host-pathogen coevolution can result in an evolutionary arms race between the two interacting species (Anderson et al. 2010). It has been proposed that NHR could be the incidental byproduct of pathogen evolution and specialization on a limited number of host plants (Antonovics et al. 2013). According to this model, NHR would be the consequence of a lack of adaptation of pathogens to the remaining plant species, resulting in a failure to overcome certain structural hurdles or to cope with particular plant immune responses.

Indeed, the outcome of an interaction between a particular genotype of a plant species and a certain genotype of a pathogen species is governed by various variables, including host structural features (e.g., organ topography) and the molecular weaponry of both opponents (see Q5 to Q7 below). On the plant side, this comprises the sum of preformed and inducible barriers and defenses while, on the pathogen side, the available arsenal of effector molecules plays a key role (Stam et al. 2014). Whereas the details differ, the overarching principles of plant immunity appear to be universally valid (Han 2019). Accordingly, the immune system of land plants can be broadly divided into two major branches, which are defined by (i) the kind of pathogen molecules recognized and (ii) the type of immune sensors and signaling pathways involved. Plasma membrane-localized transmembrane receptors primarily sense conserved microbial patterns, and cytoplasmic immune sensors typically recognize - either directly or indirectly-strainspecific pathogen effectors. Although these two major aspects of plant immunity have been considered separately in the past, more recently, substantial convergence and mutual interplay have been recognized (Ngou et al. 2020; Peng et al. 2018; Yuan et al. 2020). The numbers, types, and recognition specificities of these immune receptors vary by plant species (and in part, also, by genotype), as do downstream signaling and the actual immune outputs which, for example, comprise cell wall modifications and remodeling (Bacete et al. 2018; Malinovsky et al. 2014), including the formation of localized cell wall appositions at pathogen attack sites (Underwood 2012) and the biosynthesis and focal secretion of lineage- or species-specific toxic cargo (Bednarek 2012; Kwon and Yun 2014; Kwon et al. 2008). Resistance to pathogens can also be associated with the occurrence of localized plant cell death at attempted infection sites - a phenomenon referred to as hypersensitive response (HR). HR-like cell death symptoms are best known in plant immunity in the context of isolate-specific resistance conferred by cytoplasmic immune sensors (Balint-Kurti 2019). Thus, their occurrence in several types of nonhost interactions (Fonseca and Mysore 2019; Lindgren et al. 1986; Vleeshouwers et al. 2000) points to an involvement of such cytoplasmic immune sensors in NHR (see Q6 below).

Apart from the generalized plant immune system depicted above, which is sufficiently well equipped to fight off the vast majority of potential pathogens, there is, to the best of our knowledge, no additional mechanism in place specifically contributing to NHR. Thus, NHR relies on the very same molecular principles as all other phenomenologically defined types of plant immunity (e.g., "basal defense", "quantitative resistance", "systemic acquired resistance", and "race-specific resistance"). In this sense, NHR is just a description for the fact that the immunity-related components present in a given plant species or genotype happen to be effective enough to confer resistance against all known genotypes of a particular pathogen species. In case a pathogen is able to overcome the species- or genotype-specific immune responses of a plant, the sum of the remaining immune responses is termed "basal immunity" or "quantitative resistance". In fact, it can be assumed that the border between "resistance" and "susceptibility" (i.e., effective or noneffective NHR) in many instances is a thin line, and the fine balance between these two states may rely on single genetic factors (Fig. 1). Thus, a shift from "resistance" to "susceptibility" or vice versa might be achieved by the gain or loss of individual genes in the host or the microbe (see Q5 to Q7 below).

\section{Q3: HOW DURABLE IS NHR?}

NHR is generally considered to be an extremely durable form of plant immunity (Fonseca and Mysore 2019; Friesen 2017; Lee et al. 2016; Lee et al. 2017b). This view is largely based on the experience that, in most instances, NHR has been proven very stable both in nature and under agricultural conditions at historical time scales (decades to centuries and, possibly, millennia). Indeed, naively, it might be assumed that the adaptations on the pathogen side to overcome NHR should be complex, requiring rather long evolutionary time scales (millions of years). However, as we will discuss below in detail, the genetic constellations and molecular mechanisms underlying the phenomenon of NHR are multifaceted, ranging from simple gene-for-gene relationships to complex multilayered settings (see Q5 and Q6 below). Accordingly, the durability of NHR varies, likely depending on the type and number of critical bottlenecks that have to be overcome by a given microbial species to turn an incompatible interaction into a compatible one. It has been additionally speculated that, at least for 
bacterial pathogens, the durability of NHR might be associated with the indispensability of some genes required for the execution of NHR (such as genes involved in basic plant metabolism), which contrasts with the principal dispensability of genes coding for cytoplasmic immune sensors, resulting in more short-lived immunity (Senthil-Kumar and Mysore 2013).

Host range extensions and host jumps are evident testimonies of a pathogen's ability to overcome NHR. Although seemingly infrequent at the level of historical time frames, a number of studies have reported such events (Morris and Moury 2019; Thines 2019). A prominent recent example is the emergence of the wheat blast disease, which was enabled by a host jump of the causal agent, the fungal pathogen Magnaporthe oryzae, onto wheat (Inoue et al. 2017). It should be kept in mind that most of such instances relate to a clear shift in virulence status, from apparent avirulence (absence of recognizable signs of disease) to macroscopically visible disease symptoms. It can be assumed that an even higher number of host range extensions and host jumps may remain undiscovered because they might be based on more subtle changes in pathogen virulence, leading to intermediate outcomes (Fig. 1). Such cryptic "near hosts" or "asymptomatic hosts" as well as the capacity of some plant species to host pathogens of other plant species as endophytes (Wheeler et al. 2019) might provide hidden reservoirs of pathogen inoculum (Malcolm et al. 2013; Stergiopoulos and Gordon 2014). Factors that may promote host shifts and, thus, could affect the durability of NHR include the worldwide dispersal of pathogens as a consequence of globalization (Santini et al. 2018), climate change (Velásquez et al. 2018), and the emergence of pathogen hybrids (Depotter et al. 2016; Stukenbrock 2016), as well as the natural or artificial generation of new hybrid plant species. A prominent example of the latter is the cereal triticale, a contemporary manmade hybrid of bread wheat and rye. Introduced to agriculture in the 1960s, triticale originally was not known to be infected by any powdery mildew pathogen. However, in the early 2000 s, powdery mildew disease emerged on the new crop, and molecular analysis recently revealed that the triticale pathogen is a hybrid of the powdery mildew fungi that are pathogenic on wheat and rye, respectively (Menardo et al. 2016). Apart from anthropogenic plant hybrids, populations in so-called "hybrid zones" may act as natural springboards ("hybrid bridges") that enable or promote host range shifts (Floate and Whitham 1993). Because most of these factors (globalization and climate change as well as new hybrid hosts and hybrid pathogens) demark relatively recent events, which happened at historical time scales and, in part, might also act cooperatively, we have to await their full impact on plant immunity and our understanding of the durability of NHR.

\section{Q4: IS NHR CONSTITUTIVE OR CAN IT ALSO BE CONDITIONAL OR STAGE OR TISSUE SPECIFIC?}

The efficiency of plant immunity is generally known to be subject to environmental conditions. Exogenous abiotic factors such as temperature (Hua 2014), light quality (Ballaré 2014), photoperiod (Sharma and Bhatt 2015), and others may positively or negatively impact plant defense responses, depending on context and pathogen type. Additionally, in some instances, defense responses are restricted to certain developmental stages (e.g., young or old plants) (Develey-Rivière and Galiana 2007; $\mathrm{Hu}$ and Yang 2019) or might be specific to particular organ or

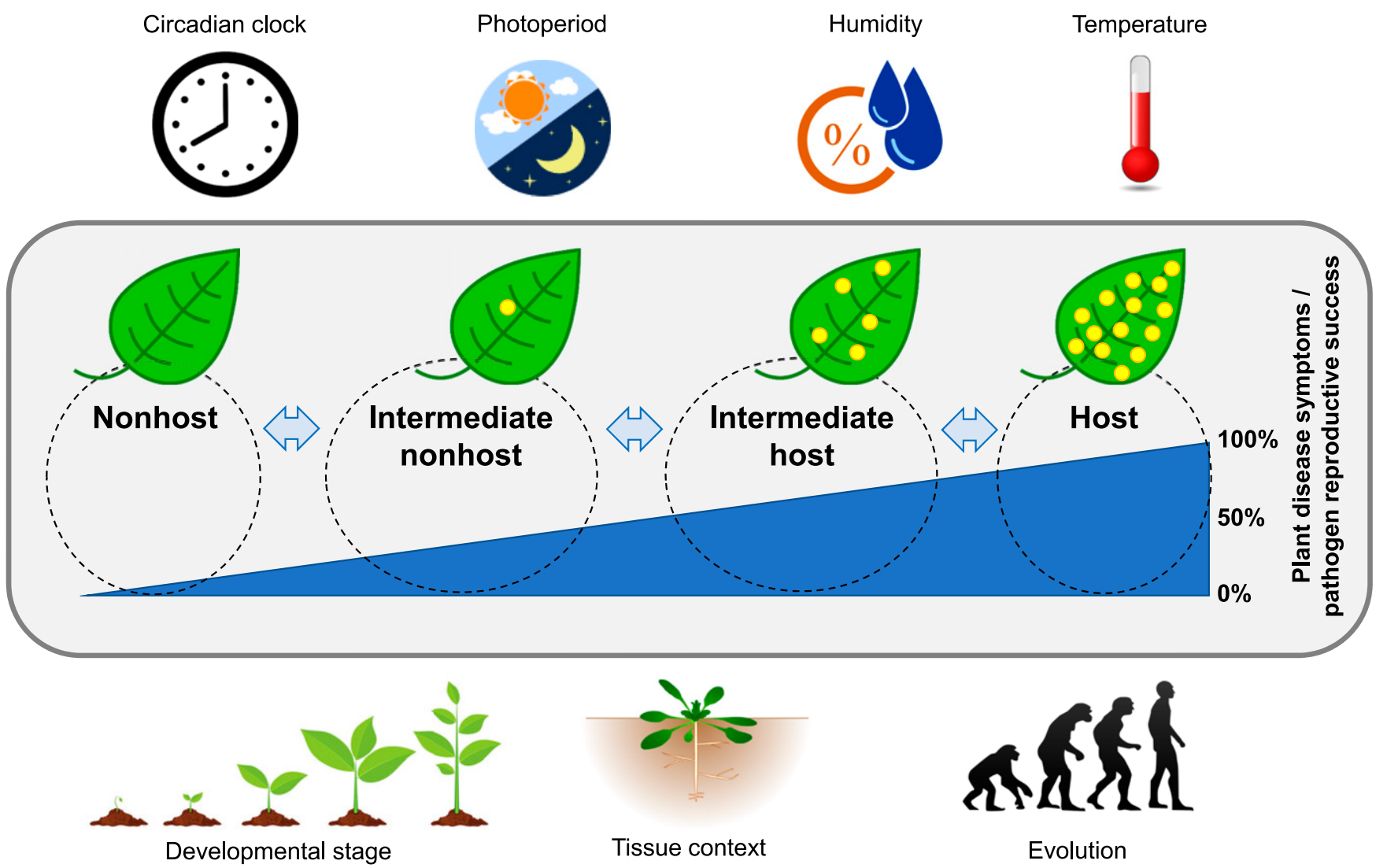

Fig. 1. Nonhost resistance is a gradual phenomenon that is modulated by various exogenous factors. The central part of the figure depicts the continuum between nonhost and host plants, with several intermediate forms possible. Yellow circles on the leaves signify the extent of pathogen colonization. Around the center, several factors (circadian clock, photoperiod, humidity, temperature, developmental stage, tissue context, and evolution) are illustrated that may condition a shift from one state to another, as indicated by the light blue double-headed arrows shown in the central part. 
tissue types (Chuberre et al. 2018; Strugala et al. 2015). This is also true for immune responses that are effective against nonadapted pathogens (i.e., in the context of NHR). Accordingly, for several plant-pathogen constellations, conditional NHR has been described (Table 1; Fig. 1) (Ayliffe and Sørensen 2019). An interesting example of conditional NHR exists in the case of pathogens that have more than one host species and where these alternative hosts are colonized exclusively by particular developmental forms of the pathogen. This is true for many rust fungi, which alternate between host species in dependence of the stage of their life cycle. In the case of the cereal rust fungi such as Puccinia graminis, asexually generated urediniospores lead to successful colonization of the grass host, whereas they fail to colonize the alternate host, dicotyledonous barberry, thus exemplifying a typical case of NHR (Jiao et al. 2017). We did not find any published evidence of the reciprocal experiment (i.e., testing the ability of sexually generated rust basidiospores generated on barberry to infect the respective grass host).

\section{Q5: HOW DOES NHR WORK?}

As stated above (Q2), NHR is governed by various factors, including host structural features and the molecular weaponry of both opponents. Critical structural characteristics are, for example, leaf topography (Hoch et al. 1987), the leaf cuticle (Yu et al. 2019), epicuticular waxes (Ishiga et al. 2013;
Uppalapati et al. 2012), cell wall composition (Engelsdorf et al. 2017), stomatal patterning and closure (Lee et al. 2013a; Melotto et al. 2006, 2017), and the presence of leaf volatiles (Sharifi et al. 2018), which all might directly or indirectly affect microbial pathogenesis. Likely as a consequence of coevolution and specialization (Antonovics et al. 2013), adapted pathogens are prepared to cope with these structural obstacles and are familiar with those present on their particular host plants and even, in some instances, require them for successful colonization (Weidenbach et al. 2014), whereas nonadapted pathogens may fail to invade a plant species due to these existing hurdles (Thordal-Christensen 2003). In addition to structural features, dedicated preformed or induced defense measures contribute to plant immunity. Preformed immunity-related molecules comprise antimicrobially active peptides (García-Olmedo et al. 1998), defense proteins, and low molecular weight compounds (phytoanticipins) (VanEtten et al. 1994). Induced defenses encompass the same molecule classes (in case of the small molecules termed phytoalexins) (Jeandet 2015) but initially require the perception of a pathogen by immune receptors and subsequent downstream signaling and, often, transcriptional reprogramming (Tsuda and Somssich 2015).

Two major experimental lines have led to the identification of genes and processes that contribute to NHR. These comprise (i) pharmacological and genetic analysis in the nonhost plant itself (predominantly loss-of-function approaches and mapping or

Table 1. Examples of conditional nonhost resistance

\begin{tabular}{|c|c|c|c|}
\hline Plant species & Pathogen species & Description & References \\
\hline \multicolumn{4}{|l|}{ Age dependent } \\
\hline Nicotiana benthamiana & Phytophthora infestans & $\begin{array}{l}\text { Mature plants are resistant, young plants are } \\
\text { susceptible }\end{array}$ & $\begin{array}{l}\text { Matsukawa et al. 2013; } \\
\text { Shibata et al. } 2011\end{array}$ \\
\hline Arabidopsis thaliana & Magnaporthe oryzae & $\begin{array}{l}\text { The entry rate of } M \text {. oryzae into old Arabidopsis } \\
\text { pen } 2-1 \text { leaves was significantly higher than that } \\
\text { into young leaves after inoculation at dusk but not } \\
\text { at dawn }\end{array}$ & Yamauchi et al. 2017 \\
\hline Lactuca saligna & Bremia lactucae & $\begin{array}{l}\text { Various quantitative trait loci determine nonhost } \\
\text { resistance to downy mildew at various } \\
\text { developmental stages (seedlings, young plants, } \\
\text { adult plants in the greenhouse, and adult plants in } \\
\text { the field) }\end{array}$ & Zhang et al. 2009 \\
\hline Hordeum vulgare & $\begin{array}{l}\text { Puccinia triticina and } \\
\text { Puccinia hordei-murini }\end{array}$ & $\begin{array}{l}\text { Mature plants of the genotypes SusPtrit and SusPmur } \\
\text { are resistant, young plants are susceptible }\end{array}$ & Atienza et al. 2004 \\
\hline Arabidopsis thaliana & $\begin{array}{l}\text { Tomato spotted wilt } \\
\text { virus (TSWV) }\end{array}$ & $\begin{array}{l}\text { Mature plants are susceptible, young plants are } \\
\text { resistant }\end{array}$ & Huang et al. 2020 \\
\hline \multicolumn{4}{|l|}{ Temperature dependent } \\
\hline Glycine max (soybean) & $\begin{array}{l}\text { Pseudomonas syringae } \\
\text { pv. glycinea }\end{array}$ & $\begin{array}{l}\text { The bacterial pathogen causes typical blight } \\
\text { symptoms on soybean plants when the bacteria } \\
\text { were grown at } 18^{\circ} \mathrm{C} \text { prior to inoculation but not } \\
\text { when derived from cultures grown at } 28^{\circ} \mathrm{C}\end{array}$ & Budde and Ullrich 2000 \\
\hline $\begin{array}{l}\text { Triticum aestivum } \\
\text { (bread wheat) }\end{array}$ & $\begin{array}{l}\text { Puccinia striiformis } \\
\text { (stripe rust) }\end{array}$ & $\begin{array}{l}\text { Resistance gene } \operatorname{Yr} 36 \text { confers resistance to a broad } \\
\text { spectrum of stripe rust races at relatively high } \\
\text { temperatures }\left(25^{\circ} \text { to } 35^{\circ} \mathrm{C}\right) \text { in adult plants }\end{array}$ & Fu et al. 2009 \\
\hline \multicolumn{4}{|l|}{ Organ or tissue specific } \\
\hline Maize (Zea mays) & Colletotrichum sublineolum & $\begin{array}{l}\text { C. sublineolum can infect maize stalks but not roots } \\
\text { and leaves }\end{array}$ & Venard and Vaillancourt 2007 \\
\hline Arabidopsis thaliana & $\begin{array}{l}\text { Hyaloperonospora } \\
\text { parasitica isolate } \mathrm{R} 1\end{array}$ & $\begin{array}{l}\text { H. parasitica isolate } R I \text { can colonize Arabidopsis } \\
\text { roots but not leaves }\end{array}$ & Hermanns et al. 2003 \\
\hline A. thaliana & Magnaporthe oryzae & $\begin{array}{l}\text { Arabidopsis roots are generally susceptible to } M \text {. } \\
\text { oryzae, whereas leaves, stems, and hypocotyls are } \\
\text { resistant }\end{array}$ & Schreiber et al. 2011 \\
\hline \multicolumn{4}{|l|}{$\begin{array}{l}\text { Photoperiod or circadian } \\
\text { clock dependent }\end{array}$} \\
\hline A. thaliana & M. oryzae & $\begin{array}{l}\text { The entry rate of } M \text {. oryzae into old Arabidopsis } \\
\text { pen } 2-1 \text { leaves was significantly higher than that } \\
\text { into young leaves after inoculation at dusk but not } \\
\text { at dawn }\end{array}$ & $\begin{array}{l}\text { Yamauchi et al. 2017; } \\
\text { Yamaura et al. } 2020\end{array}$ \\
\hline A. thaliana & M. oryzae & $\begin{array}{l}\text { Long day conditions in combination with elevated } \\
\text { humidity increase susceptibility of Arabidopsis to } \\
\text { M. oryzae }\end{array}$ & Schreiber et al. 2011 \\
\hline
\end{tabular}


cloning of genes contributing to NHR) and (ii) the ectopic expression of candidate genes, mainly conducted in heterologous plant species (gain-of-function approaches; see also Q8 below). The first components contributing to NHR were identified by seminal pharmacological inhibitor experiments in the late 1990s. Using chemical inhibitors of the cytoskeleton, Kobayashi and coworkers (1997a,b) discovered that, in particular, actin filament dynamics and, in part, microtubule function are essential for host cell entry of powdery mildew fungi into epidermal cells of nonhost plants. The pivotal role of the actin cytoskeleton in NHR was substantiated later by similar experiments in various other plant-microbe constellations (Kobayashi and Hakuno 2003; Shimada et al. 2006; Yun et al. 2003). Since then, different forward (Collins et al. 2003; Geissler et al. 2015; Lu et al. 2001) and reverse (Li et al. 2012; Senthil-Kumar et al. 2013) genetic screens, exploitation of natural genetic variation (Forsyth et al. 2010), and other molecular biological approaches identified a significant number of genes involved in various aspects of NHR (Fonseca and Mysore 2019). Fresh additions comprise two circadian clock components (CCA and LHY) and the phytochelatin synthase PCS1, required for NHR of Arabidopsis thaliana to M. oryzae (Yamaura et al. 2020) and Blumeria graminis (Hématy et al. 2020), respectively. Despite the steadily increasing number of genes known to contribute to NHR, no clear pattern emerges regarding particular cellular functions or pathways, which reinforces the notion that the critical bottlenecks are largely host and pathogen specific or at least restricted to certain taxonomic groups. An exception is possibly genes encoding components involved in the biosynthesis and extrusion of toxic cargo. This includes enzymes involved in the biosynthesis of species- or lineage-specific antimicrobials such as phytoalexins (Bednarek et al. 2009; Beyer et al. 2019; Lee et al. 2017a), as well as components of vesicle-mediated exocytosis (Kwon et al. 2008) or nonvesicular secretion (Stein et al. 2006), which appear to be decisive in NHR to various classes of pathogens.

In some instances, crosses between susceptible and resistant plant genotypes of the same or closely related species allowed the mapping of loci contributing to NHR. This often revealed the quantitative contribution of one or several genes with minor or major effects - a constellation referred to as quantitative trait loci (QTLs). Recent examples of this approach comprise the NHR of lettuce to downy mildew (Giesbers et al. 2018), barley to the wheat powdery mildew fungus (Romero et al. 2018), barley to nonadapted rust fungi (Jafary et al. 2008), and barberry and Brachypodium distachyon to wheat stem rust (Bartaula et al. 2019; Della Coletta et al. 2019). Such analyses are comparatively rare because they require fertile crosses between parental genotypes that are (partially) susceptible and resistant to the respective nonadapted pathogen. In most cases, the genes that underlie a QTL have remained obscure. However, cloning of a QTL recently revealed that lectin receptor-like kinases quantitatively affect the host status of barley to leaf rust fungi (Wang et al. 2019).

Although the genetic factors identified by these methods often have been designated as "nonhost genes", this term is inadequate and misleading and, thus, should be avoided in our view. The phrase provides the inappropriate impression that the respective genes have a dedicated function in NHR. However, as outlined above (Q2), NHR essentially relies on the regular components of plant immunity. Thus, "nonhost genes" can be assumed to have general functions in plant immunity that are not restricted to defense against nonadapted pathogens. This has been demonstrated in several instances. For example, expression of the Arabidopsis NHOl gene, which has been found to play a key role in NHR against Pseudomonas syringae isolates from bean and tobacco, is actively suppressed by the adapted pathogen, $P$. syringae. pv. tomato DC3000, an isolate fully virulent on Arabidopsis, to enable parasitism (Kang et al.
2003). Similarly, heterotrimeric G proteins play a role in immunity against adapted and nonadapted $P$. syringae pathogens in Arabidopsis (Lee et al. 2013b). In fact, to the best of our knowledge, no gene has been identified thus far that contributes substantially to NHR but has no role in any other phenomenologically defined type of plant immunity. Such cases either may not exist or might be, at least, very rare. In light of these findings, "nonhost genes" can be considered as immunityrelated genes that act as bottlenecks for particular pathogens on a given plant species or under certain conditions. Although their loss of function or ectopic overexpression leads to a loss or gain of NHR against specific pathogens, this does not necessarily affect the outcome of interactions with other nonadapted pathogens. For example, the Arabidopsis pen1 pss1 double mutant shows enhanced susceptibility to the necrotrophic fungal pathogen Fusarium virguliforme and the hemibiotrophic oomycete pathogen Phytophthora sojae but not against the bacterial pathogen Pseudomonas syringae pv. glycinea, which are all three pathogens of soybean and nonadapted to Arabidopsis (Sumit et al. 2012). As such, "nonhost genes" may contribute with context-dependent functions to NHR. We would also like to stress that, in this context, the frequent description of NHR as "multilayered" is irrelevant in our view because all phenomenologically defined types of plant immunity are multilayered.

Apart from genes that contribute to plant immunity, host genes that are required for successful infection by a given pathogen species can play an important role for successful pathogenesis (Garcia-Ruiz 2018; van Schie and Takken 2014). In some instances, lack of functional versions of such "susceptibility factors" can turn a compatible interaction into an incompatible one that bears all the hallmarks of NHR. Prominent examples of this are Mildew locus o (Mlo) genes, which are required for host cell entry and subsequent colonization of plants by powdery mildew fungi (Kusch and Panstruga 2017). Mutant mlo plants are fully resistant against powdery mildew attack, showing all characteristics of NHR (Humphry et al. 2006). Another well-known example is the requirement of particular isoforms of eukaryotic translation initiation factors (eIF4E and eIF4G) for the efficient translation of potyvirus genomes. Lack of these isoforms conditions a strong form of NHR-like resistance to these viruses (Baruah et al. 2020; Nieto et al. 2011). Thus, essential susceptibility factors-though rare-can likewise be considered as components contributing to NHR.

Next to host genes, the host microbiota is known to make a profound contribution to plant immunity by modulating the outcome of plant-pathogen interactions. Accordingly, the microbiota has been considered an "extension of the plant immune system" (Vannier et al. 2019). Underlying mechanisms comprise the stimulation of plant defense responses (termed "priming" or "induced systemic resistance") and direct microbial competition (e.g., via antibiosis, hyperparasitism, or competition for resources) (Vannier et al. 2019). Thus, it can be assumed that the plant microbiota represent another component contributing to NHR. Because the composition of, for example, the root microbiota varies with soil type and plant age (Bulgarelli et al. 2012; Lundberg et al. 2012; Wagner et al. 2016), its effect on NHR might be also variable or conditional, which could, in part, explain age-related or organ-specific NHR phenomena (Table 1). However, any convincing experimental support in favor of a contribution of the microbiota to NHR is missing to date. Comprehensive studies with germ-free plants and synthetic microbial communities will be required to explore whether the natural plant-specific root and leaf microbiota indeed restrict colonization of hosts by particular pathogens and, thus, can be considered a true determinant of NHR (i.e., protects plants in a host and pathogen speciesspecific manner) (see also Q10 below). 


\section{Q6: DO NUCLEOTIDE-BINDING LEUCINE-RICH REPEAT PROTEINS PLAY A ROLE IN NHR?}

As outlined in Q5 in detail, the mechanistic basis for NHR is often complex and multigenic. However, in some instances, mono- or oligogenic inheritance of NHR has been inferred, suggesting a putative contribution of nucleotide-binding leucine-rich repeat (NB-LRR)-type proteins, which typically engage in race-specific immunity to adapted pathogens by directly or indirectly sensing pathogen effectors (van Wersch et al. 2020). A mechanistic overlap of race-specific resistance and NHR has been proposed repeatedly and debated substantially in the past, prior to its experimental validation (Heath 1981, 1991; Newton and Crute 1989; Tosa 1992). Central to this discourse has been the question of to which degree NHR is mediated by specific recognition such as via NB-LRR-type immune receptors, or conferred by nonspecific recognition such as via pattern recognition receptors. The frequent occurrence of HR-like cell death symptoms in nonhost interactions has been interpreted as evidence for a putative contribution of specific immune receptors to NHR (Vleeshouwers et al. 2000). Indeed, early cross-isolate hybridization experiments in Puccinia graminis (stem rust) and Blumeria graminis (powdery mildew) fungi indicated a genetic basis of specific recognition, such as four loci in B. graminis f. sp. agropyri that were specifically recognized by wheat (Triticum aestivum) (Tosa 1989). Subsequent work in the blast pathogen (M. oryzae) has shown that the widespread use of wheat accessions lacking the resistance gene $R m g 6$ (=Rwt3) likely facilitated a host jump of the blast fungus from Lolium spp. onto wheat (Inoue et al. 2017). Although Rmg6 is not cloned yet, its recognition is effector based ( $P W T 3)$, suggesting specific recognition. NB-LRRs have been identified as causal proteins for NHR in the interaction of maize (Zea mays) with Xanthomonas oryzae pv. oryzicola (Zhao et al. 2005); Nicotiana benthamiana with Xanthomonas spp.; Nicotiana spp. with Phytophthora capsici (Vega-Arreguín et al. 2017), Pseudomonas spp., and Ralstonia spp. (Adlung and Bonas 2017; Schultink et al. 2017; Wei et al. 2007); Arabidopsis with nonadapted white rust (Albugo candida) (Borhan et al. 2008; Cevik et al. 2019); pigeon pea (Cajanus cajan) with Asian soybean rust (Phakopsora pachyrhizi) (Kawashima et al. 2016); and Solanum americanum with potato late blight (Phytophthora infestans) (Witek et al. 2016). Furthermore, genes encoding NB-LRRs have been implicated as candidates at resistance loci in Brachypodium distachyon and barley with wheat stripe rust (Puccinia striiformis f. sp. tritici) (Dawson et al. 2016; Gilbert et al. 2018; Li et al. 2016). Collectively, these studies have established a clear role of NB-LRR immune receptors in NHR for microbes that are closely related to adapted pathogens of a given plant species or for plant species that are closely related to a given host species, although the role of NB-LRRs in NHR to microbes that are distantly related to adapted pathogens or in distantly related plant species remains unclear. Accordingly, a concept has been proposed that the relative contribution of NB-LRRs to NHR in a given plant species may depend on the phylogenetic distance of nonpathogenic and pathogenic microbial species (SchulzeLefert and Panstruga 2011). Interestingly, the pan-repertoire of $N B-L R R$ genes in Arabidopsis thaliana comprises approximately 500 members, with approximately 200 of them present per geographically defined accession (van de Weyer et al. 2019). Only a small proportion of these (approximately 15) have documented functions in isolate-specific resistance against adapted pathogens of Arabidopsis. This raises the intriguing possibility that a considerable number of the $N B-L R R$ genes in A. thaliana might be involved in the perception of effectors from nonadapted pathogen species (i.e., may have a role in NHR). Thus, the contribution of NB-LRR proteins to NHR could be more substantial than considered thus far. Notably, despite a seemingly frequent involvement of $\mathrm{NB}$ $L R R$ genes in NHR, the occurrence of HR-like cell death is not necessarily coupled to their contribution to NHR (Gassmann 2005).

\section{Q7: DO PATHOGEN EFFECTORS PLAY A ROLE IN NHR?}

Pathogen effectors contribute to manipulations of the host such as suppressing immunity or facilitating nutrient acquisition (Toruño et al. 2016). In addition, when recognized by the plant immune system, they can also serve as determinants of avirulence. Therefore, if an effector is either recognized or unable to efficiently manipulate the host, it would potentially contribute to an incompatible interaction. The role of effectors to NHR is indirectly evident due to the documented role of NB-LRR proteins to NHR (see Q6 above). Large-scale screens based on transient expression have recently been used to systematically identify effectors that are recognized by plants in various nonhost settings (Fabro et al. 2011; Giesbers et al. 2017; Lee et al. 2014; Oh et al. 2009; Vleeshouwers et al. 2008). The effector HopAS1, present in certain pathovars of the bacterial speck pathogen Pseudomonas syringae, is recognized by $A$. thaliana and contributes to NHR (Sohn et al. 2012). More recently, studying the pan-genome repertoire of type III secreted effectors of the bacterial pathogen $P$. syringae, Laflamme and colleagues (2020) found that several effectors that partially explain host status on $A$. thaliana, particularly between closely related adapted and nonadapted strains. In fact, approximately $97 \%$ of 494 analyzed $P$. syringae strains can be recognized by $A$. thaliana based on their effectors (Laflamme et al. 2020). An alternative approach for identifying effectors potentially contributing to host status involves analyzing signatures of selective pressure on effector evolution. Based on a molecular clock, Phytophthora mirabilis and Phytophthora infestans diverged 1,300 years ago and have adapted to their corresponding hosts, Mirabilis jalapa (four o' clock flower) and S. tuberosum (potato) (Yoshida et al. 2013). Among 345 genes with signatures of positive selection, EPIC1, an inhibitor of extracellular cystatin-like proteases, was identified. Using phylogenetics, coimmunoprecipitation, site-directed mutagenesis, and biochemistry, Dong and colleagues (2014) showed that a single modification in EPICl contributes to the specific perturbation of $M$. jalapa and $S$. tuberosum orthologs of these cystatin-like proteases by their corresponding Phytophthora pathogens. These examples highlight how effectors directly contribute to host status, either through specific recognition by the plant immune system or through adaptive mutations that contribute to the manipulation of the host (Stam et al. 2014).

\section{Q8: HOW DOES NHR CONTRIBUTE TO THE SIZE OF A PATHOGENS' HOST RANGE?}

The host range of a pathogen is demarcated by the differentiation of its plant host and nonhost species. As outlined above (Q1), this separation is not always easy and straightforward and sometimes is blurred (Morris and Moury 2019) (Fig. 1). Nonetheless, plant pathogens can vary widely in the size and diversity of their host ranges (i.e., the effectivity of NHR to them differs among plant species). Extremes include the necrotrophs Botrytis cinerea and Sclerotinia sclerotiorum, with host ranges including hundreds of species, versus the obligate biotrophs Blumeria graminis and Puccinia hordei that specialize in a single genus (Boland and Hall 1994; Dean 
et al. 2012; Dracatos et al. 2018). Host ranges can shift or expand as plants and pathogens move into new environments encountering novel species. A recent example is Puccinia psidii, a rust pathogen on native Myrtaceae spp. that began infecting eucalypts introduced into Brazil (Grgurinovic et al. 2006). This pathogen has now been introduced into Australia, which threatens a wide range of native Myrtaceae spp. (Carnegie and Lidbetter 2012). Novel host species can also emerge as plant species are moved across the world. An example is Cocoa swollen shoot virus that originally was a pathogen of the native West African forest tree Cola chlamydantha but emerged as a novel pathogen of cocoa (Theobroma cacao) soon after its introduction to West Africa at the end of the nineteenth century (Thresh 1982). Although host range is a dynamic trait, the factors contributing to its diversity and size are only beginning to be uncovered.

Host range can be dependent on the life cycle of the pathogen, such as in the case of stem rust (Puccinia graminis), which infects Triticeae species at the uredinial stage and Berberis and Mahonia spp. at the basidial stage (Jin et al. 2014), or Melampsora larici-populina, infecting larch (Larix spp., aecial host) and poplar (Populus spp., telial host) (Lorrain et al. 2018). Interestingly, the putative effector genes encoding small secreted peptides of $M$. larici-populina expressed in the infection process of larch and poplar are largely shared, suggesting that a similar effector repertoire is used in these highly divergent hosts (conifer versus dicot) (Lorrain et al. 2018). In some systems, the population structure of pathogens and hosts are identical, as in the case of Magnaporthe oryzae, where isolates infecting rice are more closely related to each other than isolates infecting other grass species (Gladieux et al. 2018). In contrast, pathogen genomes may have no predictive power for determining the plant species they infect, as observed for other systems such as Botrytis cinerea (Mercier et al. 2019). Yaegashi (1978) and Tosa (1989) found that the host ranges of M. oryzae and Blumeria graminis, respectively, were determined by several avirulence genes (i.e., major effect genes). This provided some of the earliest evidence that effectors were governing the host range of fungal pathogens (see also Q6 and Q7 above). In several other instances, pathogen effectors have been shown to play a major role. Examples include (i) effectors directly influencing the set of hosts that are infected, such the p33, p18, and p13 proteins in Citrus tristeza virus (Tatineni et al. 2011); (ii) the limiting of host range by carrying effectors that are recognized by nonhost plant species (see examples in Q6 and Q7); or (iii) effectors that specifically adapt to their host, as documented for EPIC1 in Phytophthora spp. (Dong et al. 2014). However, it remains unknown whether host range is indeed predominantly conditioned by the effector repertoire and, thus, the balance between defense suppression (i.e., ineffective NHR) and pathogen detection (i.e., effective NHR) in a given plant species. The critical role of host structural features (Hoch et al. 1987; Ishiga et al. 2013; Uppalapati et al. 2012; Yu et al. 2019) and documented (Forsyth et al. 2010) and presumptive (Rajaraman et al. 2016) pattern recognition receptors in NHR indicate that this is a simplistic view and "host range", in fact, is the outcome of a complex interaction conditioned by various factors.

\section{Q9: CAN WE TRANSFER (ASPECTS OF) NHR TO OTHER PLANT SPECIES? YES, WE CAN!}

The prospect of transferring durable resistance from distantly related (nonhost) species into crops has been a central motivation for research in the field. Norman Borlaug highlighted the potential benefit for humanity through transferring the immunity of rice to cereal rusts into other cereal crops that are susceptible to rust disease (Borlaug 2000). Accordingly, the NHR of rice to cereal rusts has been the subject of several recent studies (Ayliffe et al. 2011 a,b; Zhao et al. 2016). More broadly, in the cereals, introgression of chromosomes and segments into wheat have been performed with over 50 diverse species, with the aim of transferring aspects of NHR (Wulff and Moscou 2014). By transferring chromosomes of rye (Secale cereale) into wheat, Riley and Macer (1966) found wheat stripe rust (Puccinia striiformis) resistance was transferable and monogenic, whereas no transferred chromosome conferred resistance to wheat leaf rust (Puccinia triticina). These efforts, along with others in diverse plant systems, were successful at transferring agronomically important resistance into important crop species. More recently, transgenic approaches have been used for the interspecific transfer of genes, in particular immune receptors, involved in resistance to nonadapted pathogens (Rodriguez-Moreno et al. 2017; Wulff et al. 2011). Maize Rxol encodes an NB-LRR that contributes to NHR to several bacterial species and was successfully transferred to rice (Zhao et al. 2005). The transmembrane receptor kinase EFR from $A$. thaliana, which recognizes a conserved 18-amino-acid N-terminal epitope (elf18) from the prokaryotic translation factor EF-Tu, functions in tomato (Solanum lycopersicum) (Lacombe et al. 2010), potato (S. tuberosum) (Boschi et al. 2017), Medicago truncatula (Pfeilmeier et al. 2019), rice ( $\mathrm{Lu}$ et al. 2015; Schwessinger et al. 2015), and wheat (Schoonbeek et al. 2015). Similarly, the receptor kinase Xa21 from rice functions against diverse Xanthomonas spp. when transferred into $N$. benthamiana (Holton et al. 2015), orange (Citrus sinensis) (Mendes et al. 2010), and banana (Musa sp.) (Tripathi et al. 2014). Kawashima and colleagues (2016) identified CcRppl, an NB-LRR-encoding gene identified in Cajanus cajan that confers resistance to Phakopsora pachyrhizi (Asian soybean rust). Stable expression of CcRppl in soybean (Glycine max) driven by a polyubiquitin promoter recapitulated the same level of resistance to Phakopsora pachyrhizi as observed in $C$. cajan (Kawashima et al. 2016). Apart from immune receptors, a number of different genes have been transgenically expressed in various plant species to boost NHR to a diverse panel of pathogens (Langenbach et al. 2016; Wang et al. 2018). In summary, the interspecific transfer of immune receptors and other genes is a feasible strategy for transferring NHR, although the acceptance of the technology by the public remains a major hurdle.

\section{Q10: HOW CAN WE FURTHER EXPAND OUR KNOWLEDGE ABOUT NHR?}

Identifying the molecular basis of NHR has and will continue to be a major task for the field of plant-microbe interactions. In part, this challenge is associated with the inherent complexity of the plant immune system, which is multilayered and involves diverse signaling and execution pathways. Below, we highlight a range of potential strategies that could be used to further develop the field by addressing additional aspects of NHR.

\section{Forward genetic screens.}

There is still scope to develop new genetic screens that may uncover genes that contribute to NHR. Previous approaches, mainly performed in A. thaliana, have yielded several important players such as the PENETRATION (PEN) genes in Arabidopsis (Collins et al. 2003; Hématy et al. 2020; Lipka et al. 2005; Stein et al. 2006). Further screens in diverse plant species may uncover additional genetic variation not easily identified within $A$. thaliana (e.g., due to genetic redundancy, essentiality, or lineage-specificity). 


\section{Transient expression of effectors.}

With the wealth of pathogen genomes and putative effectors, several research groups have adopted a strategy to identify effectors contributing to NHR through transient expression in nonhost plant species. This has uncovered a potential role of effector-triggered immunity in a range of interactions such as Capsicum annuum-Phytophthora infestans (Lee et al. 2014), N. benthamiana-Zymoseptoria tritici (Kettles et al. 2017), and Lactuca saligna-Bremia lactucae (Giesbers et al. 2017). Although these approaches work well for plant species amenable to transient expression, there are currently limited opportunities in a wide range of species to use this approach, particularly monocot species. Several tools have recently been developed, including virus-mediated overexpression (Lee et al. 2014) and Agrobacterium-based transient transformation (Andrieu et al. 2012; Sharma et al. 2020), and there is still scope to develop further high-throughput approaches using heterologous expression of effectors in virulent pathogens (Fabro et al. 2011; Sohn et al. 2007).

\section{Reverse genetic screens.}

Recent advances in high-throughput transformation platforms in plants (Lowe et al. 2016), in parallel with progress in targeted mutagenesis using the CRISPR/Cas9 system (Belhaj et al. 2013; Luo et al. 2016), have the potential to rapidly explore the functional role of diverse candidate genes in NHR in a broad panel of plant species. This could include transforming specific gene families from nonhost species into host species or mutagenesis of complex gene families in nonhost species. For pathogens, considerable progress in $P$. syringae using either systematic knockouts of type III secreted effectors (Wei et al. 2007; Wei et al. 2015, 2018) or pan-genomic approaches (Laflamme et al. 2020) highlight a strategy for future work on pathogens from other kingdoms.

\section{Microbiota.}

The role of microbiota in the context of NHR is presently understudied. It will be interesting to find out whether the presence of particular root-associated or foliar microbes plays a role in limiting pathogen host ranges. This will require experiments with germ-free plants and synthetic microbial communities (Vannier et al. 2019).

\section{Cryptic plant infections.}

The full host range of most microbial pathogens remains largely enigmatic due to the potential occurrence of cryptic plant infections on "intermediate nonhost" species (Fig. 1). Ultradeep DNA genome and transcriptome sequencing efforts hold promise for detecting evidence of the otherwise unrecognized presence of certain microbial intruders. Careful exploration of the respective data sets will expand our knowledge about the true spectrum of plants that can be colonized by a given pathogen.

\section{CONCLUDING REMARKS}

Interestingly, according to our searches, the term NHR is, with few exceptions (Antonovics et al. 2013), largely absent from literature about human and animal immunity. In the latter fields, "immunity" apparently is considered in a more comprehensive way, essentially without the strict demarcation of "host resistance" and NHR. We believe that the discrimination in plant biology created considerable confusion, leading to unnecessary and confounding phrases such as "nonhost genes" which, in part, also applies to other phenomenologically defined subtypes of disease resistance. Thus, we feel that it may be time to move to a more holistic view of plant immunity and use the traditional descriptive terms (including NHR) more cautiously wherever possible.

\section{ACKNOWLEDGMENTS}

We thank the IS-MPMI for inviting us to write this review article and S. Hacquard for helpful discussions on the role of microbiota. We apologize to all colleagues whose work we could not cite due to length limitations.

\section{LITERATURE CITED}

Adlung, N., and Bonas, U. 2017. Dissecting virulence function from recognition: Cell death suppression in Nicotiana benthamiana by XopQ/HopQ1-family effectors relies on EDS1-dependent immunity. Plant J. 91:430-442.

Anderson, J. P., Gleason, C. A., Foley, R. C., Thrall, P. H., Burdon, J. B., and Singh, K. B. 2010. Plants versus pathogens: An evolutionary arms race. Funct. Plant Biol. 37:499-512.

Andrieu, A., Breitler, J. C., Siré, C., Meynard, D., Gantet, P., and Guiderdoni, E. 2012. An in planta, Agrobacterium-mediated transient gene expression method for inducing gene silencing in rice (Oryza sativa L.) leaves. Rice (N. Y.) 5:23.

Antonovics, J., Boots, M., Ebert, D., Koskella, B., Poss, M., and Sadd, B. M. 2013. The origin of specificity by means of natural selection: Evolved and nonhost resistance in host-pathogen interactions. Evolution 67:1-9.

Atienza, S. G., Jafary, H., and Niks, R. E. 2004. Accumulation of genes for susceptibility to rust fungi for which barley is nearly a nonhost results in two barley lines with extreme multiple susceptibility. Planta 220: 71-79.

Ayliffe, M., Devilla, R., Mago, R., White, R., Talbot, M., Pryor, A., and Leung, H. 2011a. Nonhost resistance of rice to rust pathogens. Mol. Plant-Microbe Interact. 24:1143-1155.

Ayliffe, M., Jin, Y., Kang, Z., Persson, M., Steffenson, B., Wang, S., and Leung, H. 2011b. Determining the basis of nonhost resistance in rice to cereal rusts. Euphytica 179:33-40.

Ayliffe, M., and Sørensen, C. K. 2019. Plant nonhost resistance: Paradigms and new environments. Curr. Opin. Plant Biol. 50:104-113.

Bacete, L., Mélida, H., Miedes, E., and Molina, A. 2018. Plant cell wallmediated immunity: Cell wall changes trigger disease resistance responses. Plant J. 93:614-636.

Balint-Kurti, P. 2019. The plant hypersensitive response: Concepts, control and consequences. Mol. Plant Pathol. 20:1163-1178.

Ballaré, C. L. 2014. Light regulation of plant defense. Annu. Rev. Plant Biol. 65:335-363.

Bartaula, R., Melo, A. T. O., Kingan, S., Jin, Y., and Hale, I. 2019. Mapping non-host resistance to the stem rust pathogen in an interspecific barberry hybrid. BMC Plant Biol. 19:319.

Baruah, A., Sivalingam, P. N., Fatima, U., and Senthil-Kumar, M. 2020 Non-host resistance to plant viruses: What do we know? Physiol. Mol. Plant Pathol. 111:101506.

Bednarek, P. 2012. Chemical warfare or modulators of defence responsesThe function of secondary metabolites in plant immunity. Curr. Opin. Plant Biol. 15:407-414.

Bednarek, P., Piślewska-Bednarek, M., Svatoš, A., Schneider, B., Doubský, J., Mansurova, M., Humphry, M., Consonni, C., Panstruga, R., SanchezVallet, A., Molina, A., and Schulze-Lefert, P. 2009. A glucosinolate metabolism pathway in living plant cells mediates broad-spectrum antifungal defense. Science 323:101-106.

Belhaj, K., Chaparro-Garcia, A., Kamoun, S., and Nekrasov, V. 2013. Plant genome editing made easy: Targeted mutagenesis in model and crop plants using the CRISPR/Cas system. Plant Methods 9:39.

Bettgenhaeuser, J., Gilbert, B., Ayliffe, M., and Moscou, M. J. 2014. Nonhost resistance to rust pathogens-A continuation of continua. Front. Plant Sci. 5:664.

Beyer, S. F., Beesley, A., Rohmann, P. F. W., Schultheiss, H., Conrath, U., and Langenbach, C. J. G. 2019. The Arabidopsis non-host defenceassociated coumarin scopoletin protects soybean from Asian soybean rust. Plant J. 99:397-413.

Boland, G. J., and Hall, R. 1994. Index of plant hosts of Sclerotinia sclerotiorum. Can. J. Plant Pathol. 16:93-108.

Borhan, M. H., Gunn, N., Cooper, A., Gulden, S., Tör, M., Rimmer, S. R., and Holub, E. B. 2008. WRR4 encodes a TIR-NB-LRR protein that confers broad-spectrum white rust resistance in Arabidopsis thaliana to four physiological races of Albugo candida. Mol. Plant-Microbe Interact. 21:757-768.

Borlaug, N. E. 2000. Ending world hunger. The promise of biotechnology and the threat of antiscience zealotry. Plant Physiol. 124:487-490. 
Boschi, F., Schvartzman, C., Murchio, S., Ferreira, V., Siri, M. I., Galván, G. A., Smoker, M., Stransfeld, L., Zipfel, C., Vilaró, F. L., and DallaRizza, M. 2017. Enhanced bacterial wilt resistance in potato through expression of Arabidopsis EFR and introgression of quantitative resistance from Solanum commersonii. Front. Plant Sci. 8:1642.

Brown, J. K. M., and Tellier, A. 2011. Plant-parasite coevolution: Bridging the gap between genetics and ecology. Annu. Rev. Phytopathol. 49: 345-367.

Budde, I. P., and Ullrich, M. S. 2000. Interactions of Pseudomonas syringae pv. glycinea with host and nonhost plants in relation to temperature and phytotoxin synthesis. Mol. Plant-Microbe Interact. 13:951-961.

Bulgarelli, D., Rott, M., Schlaeppi, K., Ver Loren van Themaat, E., Ahmadinejad, N., Assenza, F., Rauf, P., Huettel, B., Reinhardt, R. Schmelzer, E., Peplies, J., Gloeckner, F. O., Amann, R., Eickhorst, T., and Schulze-Lefert, P. 2012. Revealing structure and assembly cues for Arabidopsis root-inhabiting bacterial microbiota. Nature 488:91-95.

Burdon, J. J., and Thrall, P. H. 2009. Coevolution of plants and their pathogens in natural habitats. Science 324:755-756.

Carnegie, A. J., and Lidbetter, J. R. 2012. Rapidly expanding host range for Puccinia psidii sensu lato in Australia. Australas. Plant Pathol. 41: 13-29.

Cevik, V., Boutrot, F., Apel, W., Robert-Seilaniantz, A., Furzer, O. J., Redkar, A., Castel, B., Kover, P. X., Prince, D. C., Holub, E. B., and Jones, J. D. G. 2019. Transgressive segregation reveals mechanisms of Arabidopsis immunity to Brassica-infecting races of white rust (Albugo candida). Proc. Natl. Acad. Sci. U.S.A. 116:2767-2773.

Chuberre, C., Plancot, B., Driouich, A., Moore, J. P., Bardor, M., Gügi, B., and Vicré, M. 2018. Plant immunity is compartmentalized and specialized in roots. Front. Plant Sci. 9:1692.

Collins, N. C., Thordal-Christensen, H., Lipka, V., Bau, S., Kombrink, E., Qiu, J. L., Hückelhoven, R., Stein, M., Freialdenhoven, A., Somerville, S. C., and Schulze-Lefert, P. 2003. SNARE-protein-mediated disease resistance at the plant cell wall. Nature 425:973-977.

Dawson, A. M., Ferguson, J. N., Gardiner, M., Green, P., Hubbard, A., and Moscou, M. J. 2016. Isolation and fine mapping of Rps6: An intermediate host resistance gene in barley to wheat stripe rust. Theor. Appl. Genet. 129:831-843.

Dean, R., Van Kan, J. A. L., Pretorius, Z. A., Hammond-Kosack, K. E., Di Pietro, A., Spanu, P. D., Rudd, J. J., Dickman, M., Kahmann, R., Ellis, J., and Foster, G. D. 2012. The Top 10 fungal pathogens in molecular plant pathology. Mol. Plant Pathol. 13:414-430.

Della Coletta, R., Hirsch, C. N., Rouse, M. N., Lorenz, A., and Garvin, D. F. 2019. Genomic dissection of nonhost resistance to wheat stem rust in Brachypodium distachyon. Mol. Plant-Microbe Interact. 32: 392-400.

Depotter, J. R., Seidl, M. F., Wood, T. A., and Thomma, B. P. 2016. Interspecific hybridization impacts host range and pathogenicity of filamentous microbes. Curr. Opin. Microbiol. 32:7-13.

Develey-Rivière, M.-P., and Galiana, E. 2007. Resistance to pathogens and host developmental stage: A multifaceted relationship within the plant kingdom. New Phytol. 175:405-416.

Dong, S., Stam, R., Cano, L. M., Song, J., Sklenar, J., Yoshida, K., Bozkurt, T. O., Oliva, R., Liu, Z., Tian, M., Win, J., Banfield, M. J., Jones, A. M. E., van der Hoorn, R. A. L., and Kamoun, S. 2014. Effector specialization in a lineage of the Irish potato famine pathogen. Science 343:552-555.

Dracatos, P. M., Haghdoust, R., Singh, D., and Park, R. F. 2018. Exploring and exploiting the boundaries of host specificity using the cereal rust and mildew models. New Phytol. 218:453-462.

Engelsdorf, T., Will, C., Hofmann, J., Schmitt, C., Merritt, B. B., Rieger, L., Frenger, M. S., Marschall, A., Franke, R. B., Pattathil, S., and Voll, L. M. 2017. Cell wall composition and penetration resistance against the fungal pathogen Colletotrichum higginsianum are affected by impaired starch turnover in Arabidopsis mutants. J. Exp. Bot. 68:701-713.

Fabro, G., Steinbrenner, J., Coates, M., Ishaque, N., Baxter, L., Studholme, D. J., Körner, E., Allen, R. L., Piquerez, S. J. M., Rougon-Cardoso, A., Greenshields, D., Lei, R., Badel, J. L., Caillaud, M.-C., Sohn, K.-H., Van den Ackerveken, G., Parker, J. E., Beynon, J., and Jones, J. D. G. 2011. Multiple candidate effectors from the oomycete pathogen Hyaloperonospora arabidopsidis suppress host plant immunity. PLoS Pathog. 7: e1002348.

Floate, K. D., and Whitham, T. G. 1993. The "hybrid bridge" hypothesis: Host shifting via plant hybrid swarms. Am. Nat. 141:651-662.

Fonseca, J. P., and Mysore, K. S. 2019. Genes involved in nonhost disease resistance as a key to engineer durable resistance in crops. Plant Sci. 279: 108-116.

Forsyth, A., Mansfield, J. W., Grabov, N., de Torres, M., Sinapidou, E., and Grant, M. R. 2010. Genetic dissection of basal resistance to Pseudomonas syringae pv. phaseolicola in accessions of Arabidopsis. Mol. PlantMicrobe Interact. 23:1545-1552.

Friesen, T. L. 2017. Nicotiana benthamiana as a nonhost of Zymoseptoria tritici. New Phytol. 213:7-9.

Fu, D., Uauy, C., Distelfeld, A., Blechl, A., Epstein, L., Chen, X., Sela, H., Fahima, T., and Dubcovsky, J. 2009. A kinase-START gene confers temperature-dependent resistance to wheat stripe rust. Science 323:1357-1360.

García-Olmedo, F., Molina, A., Alamillo, J. M., and Rodríguez-Palenzuéla, P. 1998. Plant defense peptides. Biopolymers 47:479-491.

Garcia-Ruiz, H. 2018. Susceptibility genes to plant viruses. Viruses 10:484.

Gassmann, W. 2005. Natural variation in the Arabidopsis response to the avirulence gene hopPsyA uncouples the hypersensitive response from disease resistance. Mol. Plant-Microbe Interact. 18:1054-1060.

Geissler, K., Eschen-Lippold, L., Naumann, K., Schneeberger, K., Weigel, D., Scheel, D., Rosahl, S., and Westphal, L. 2015. Mutations in the EDRl gene alter the response of Arabidopsis thaliana to Phytophthora infestans and the bacterial PAMPs flg22 and elf18. Mol. PlantMicrobe Interact. 28:122-133.

Giesbers, A. K. J., Boer, E. D., Braspenning, D. N. J., Bouten, T. P. H., Specken, J. W., van Kaauwen, M. P. W., Visser, R. G. F., Niks, R. E., and Jeuken, M. J. W. 2018. Bidirectional backcrosses between wild and cultivated lettuce identify loci involved in nonhost resistance to downy mildew. Theor. Appl. Genet. 131:1761-1776.

Giesbers, A. K. J., Pelgrom, A. J. E., Visser, R. G. F., Niks, R. E., Van den Ackerveken, G., and Jeuken, M. J. W. 2017. Effector-mediated discovery of a novel resistance gene against Bremia lactucae in a nonhost lettuce species. New Phytol. 216:915-926.

Gilbert, B., Bettgenhaeuser, J., Upadhyaya, N., Soliveres, M., Singh, D., Park, R. F., Moscou, M. J., and Ayliffe, M. 2018. Components of Brachypodium distachyon resistance to nonadapted wheat stripe rust pathogens are simply inherited. PLoS Genet. 14:e1007636.

Gladieux, P., Condon, B., Ravel, S., Soanes, D., Maciel, J. L. N., Nhani, A., Jr., Chen, L., Terauchi, R., Lebrun, M.-H., Tharreau, D., Mitchell, T., Pedley, K. F., Valent, B., Talbot, N. J., Farman, M., and Fournier, E. 2018. Gene flow between divergent cereal- and grass-specific lineages of the rice blast fungus Magnaporthe oryzae. MBio 9:e01219-17.

Grgurinovic, C. A., Walsh, D., and Macbeth, F. 2006. Eucalyptus rust caused by Puccinia psidii and the threat it poses to Australia. EPPO Bull. 36:486-489.

Han, G.-Z. 2019. Origin and evolution of the plant immune system. New Phytol. 222:70-83.

Heath, M. C. 1977. A comparative study of non-host interactions with rust fungi. Physiol. Plant Pathol. 10:73-88.

Heath, M. C. 1981. A generalized concept of host-parasite specificity. Phytopathology 71:1121-1123.

Heath, M. C. 1991. The role of gene-for-gene interactions in the determination of host species specificity. Phytopathology 81:127-130.

Heath, M. C. 2000. Nonhost resistance and nonspecific plant defenses. Curr. Opin. Plant Biol. 3:315-319.

Hématy, K., Lim, M., Cherk, C., Piślewska-Bednarek, M., SanchezRodriguez, C., Stein, M., Fuchs, R., Klapprodt, C., Lipka, V., Molina, A., Grill, E., Schulze-Lefert, P., Bednarek, P., and Somerville, S. 2020. Moonlighting function of phytochelatin synthase 1 in extracellular defense against fungal pathogens. Plant Physiol. 182:1920-1932.

Hermanns, M., Slusarenko, A. J., and Schlaich, N. L. 2003. Organspecificity in a plant disease is determined independently of $\mathrm{R}$ gene signaling. Mol. Plant-Microbe Interact. 16:752-759.

Hoch, H. C., Staples, R. C., Whitehead, B., Comeau, J., and Wolf, E. D. 1987. Signaling for growth orientation and cell differentiation by surface topography in Uromyces. Science 235:1659-1662.

Holton, N., Nekrasov, V., Ronald, P. C., and Zipfel, C. 2015. The phylogenetically-related pattern recognition receptors EFR and XA21 recruit similar immune signaling components in monocots and dicots. PLoS Pathog. 11:e1004602.

Hu, L., and Yang, L. 2019. Time to fight: Molecular mechanisms of agerelated resistance. Phytopathology 109:1500-1508.

Hua, J. 2014. Temperature and plant immunity. Pages 163-180 in: Temperature and Plant Development. K. A. Franklin and P. A. Wigge, eds. John Wiley \& Sons, Hoboken, NJ, U.S.A.

Huang, Y., Hong, H., Xu, M., Yan, J., Dai, J., Wu, J., Feng, Z., Zhu, M., Zhang, Z., Yuan, X., Ding, X., and Tao, X. 2020. Developmentally regulated Arabidopsis thaliana susceptibility to tomato spotted wilt virus infection. Mol. Plant Pathol. 21:985-998.

Humphry, M., Consonni, C., and Panstruga, R. 2006. mlo-based powdery mildew immunity: Silver bullet or simply non-host resistance? Mol. Plant Pathol. 7:605-610.

Inoue, Y., Vy, T. T. P., Yoshida, K., Asano, H., Mitsuoka, C., Asuke, S., Anh, V. L., Cumagun, C. J. R., Chuma, I., Terauchi, R., Kato, K., 
Mitchell, T., Valent, B., Farman, M., and Tosa, Y. 2017. Evolution of the wheat blast fungus through functional losses in a host specificity determinant. Science 357:80-83.

Ishiga, Y., Upplapapti, S., and Mysore, K. S. 2013. Expression analysis reveals a role for hydrophobic or epicuticular wax signals in prepenetration structure formation of Phakopsora pachyrhizi. Plant Signal. Behav. 8:e26959.

Jafary, H., Albertazzi, G., Marcel, T. C., and Niks, R. E. 2008. High diversity of genes for nonhost resistance of barley to heterologous rust fungi. Genetics 178:2327-2339.

Jeandet, P. 2015. Phytoalexins: Current progress and future prospects. Molecules 20:2770-2774.

Jiao, M., Tan, C., Wang, L., Guo, J., Zhang, H., Kang, Z., and Guo, J. 2017. Basidiospores of Puccinia striiformis f. sp. tritici succeed to infect barberry, while urediniospores are blocked by non-host resistance. Protoplasma 254:2237-2246.

Jin, Y., Rouse, M., and Groth, J. 2014. Population diversity of Puccinia graminis is sustained through sexual cycle on alternate hosts. J. Integr. Agric. 13:262-264.

Kang, L., Li, J., Zhao, T., Xiao, F., Tang, X., Thilmony, R., He, S., and Zhou, J.-M. 2003. Interplay of the Arabidopsis nonhost resistance gene NHO1 with bacterial virulence. Proc. Natl. Acad. Sci. U.S.A. 100:3519-3524.

Kawashima, C. G., Guimarães, G. A., Nogueira, S. R., MacLean, D., Cook, D. R., Steuernagel, B., Baek, J., Bouyioukos, C., Melo, Bdo. V., Tristão, G., de Oliveira, J. C., Rauscher, G., Mittal, S., Panichelli, L., Bacot, K., Johnson, E., Iyer, G., Tabor, G., Wulff, B. B. H., Ward, E., Rairdan, G. J., Broglie, K. E., Wu, G., van Esse, H. P., Jones, J. D. G., and Brommonschenkel, S. H. 2016. A pigeonpea gene confers resistance to Asian soybean rust in soybean. Nat. Biotechnol. 34:661-665.

Kettles, G. J., Bayon, C., Canning, G., Rudd, J. J., and Kanyuka, K. 2017. Apoplastic recognition of multiple candidate effectors from the wheat pathogen Zymoseptoria tritici in the nonhost plant Nicotiana benthamiana. New Phytol. 213:338-350.

Kobayashi, I., and Hakuno, H. 2003. Actin-related defense mechanism to reject penetration attempt by a non-pathogen is maintained in tobacco BY-2 cells. Planta 217:340-345.

Kobayashi, Y., Kobayashi, I., Funaki, Y., Fujimoto, S., Takemoto, T., and Kunoh, H. 1997a. Dynamic reorganization of microfilaments and microtubules is necessary for the expression of non-host resistance in barley coleoptile cells. Plant J. 11:525-537.

Kobayashi, Y., Yamada, M., Kobayashi, I., and Kunoh, H. 1997b. Actin microfilaments are required for the expression of nonhost resistance in higher plants. Plant Cell Physiol. 38:725-733.

Kusch, S., and Panstruga, R. 2017. mlo-Based resistance: An apparently universal "weapon" to defeat powdery mildew disease. Mol. PlantMicrobe Interact. 30:179-189.

Kwon, C., Bednarek, P., and Schulze-Lefert, P. 2008. Secretory pathways in plant immune responses. Plant Physiol. 147:1575-1583.

Kwon, C., and Yun, H. S. 2014. Plant exocytic secretion of toxic compounds for defense. Toxicol. Res. 30:77-81.

Lacombe, S., Rougon-Cardoso, A., Sherwood, E., Peeters, N., Dahlbeck, D., van Esse, H. P., Smoker, M., Rallapalli, G., Thomma, B. P. H. J., Staskawicz, B., Jones, J. D. G., and Zipfel, C. 2010. Interfamily transfer of a plant pattern-recognition receptor confers broad-spectrum bacterial resistance. Nat. Biotechnol. 28:365-369.

Laflamme, B., Dillon, M. M., Martel, A., Almeida, R. N. D., Desveaux, D., and Guttman, D. S. 2020. The pan-genome effector-triggered immunity landscape of a host-pathogen interaction. Science 367:763-768.

Langenbach, C., Schultheiss, H., Rosendahl, M., Tresch, N., Conrath, U., and Goellner, K. 2016. Interspecies gene transfer provides soybean resistance to a fungal pathogen. Plant Biotechnol. J. 14:699-708.

Lee, H.-A., Kim, S., Kim, S., and Choi, D. 2017a. Expansion of sesquiterpene biosynthetic gene clusters in pepper confers nonhost resistance to the Irish potato famine pathogen. New Phytol. 215:1132-1143.

Lee, H.-A., Kim, S.-Y., Oh, S.-K., Yeom, S.-I., Kim, S.-B., Kim, M.-S., Kamoun, S., and Choi, D. 2014. Multiple recognition of RXLR effectors is associated with nonhost resistance of pepper against Phytophthora infestans. New Phytol. 203:926-938.

Lee, H.-A., Lee, H.-Y., Seo, E., Lee, J., Kim, S.-B., Oh, S., Choi, E., Choi, E., Lee, S. E., and Choi, D. 2017b. Current understandings of plant nonhost resistance. Mol. Plant-Microbe Interact. 30:5-15.

Lee, S., Ishiga, Y., Clermont, K., and Mysore, K. S. 2013a. Coronatine inhibits stomatal closure and delays hypersensitive response cell death induced by nonhost bacterial pathogens. PeerJ 1:e34.

Lee, S., Rojas, C. M., Ishiga, Y., Pandey, S., and Mysore, K. S. 2013b. Arabidopsis heterotrimeric G-proteins play a critical role in host and nonhost resistance against Pseudomonas syringae pathogens. PLoS One 8:e82445.
Lee, S., Whitaker, V. M., and Hutton, S. F. 2016. Mini Review: Potential applications of non-host resistance for crop improvement. Front. Plant Sci. 7:997.

Li, K., Hegarty, J., Zhang, C., Wan, A., Wu, J., Guedira, G. B., Chen, X., Muñoz-Amatriaín, M., Fu, D., and Dubcovsky, J. 2016. Fine mapping of barley locus Rps6 conferring resistance to wheat stripe rust. Theor. Appl. Genet. 129:845-859.

Li, W., Xu, Y.-P., Zhang, Z.-X., Cao, W.-Y., Li, F., Zhou, X., Chen, G.-Y., and Cai, X.-Z. 2012. Identification of genes required for nonhost resistance to Xanthomonas oryzae pv. oryzae reveals novel signaling components. PLoS One 7:e42796.

Lindgren, P. B., Peet, R. C., and Panopoulos, N. J. 1986. Gene cluster of Pseudomonas syringae pv. "phaseolicola" controls pathogenicity of bean plants and hypersensitivity of nonhost plants. J. Bacteriol. 168: 512-522.

Lipka, V., Dittgen, J., Bednarek, P., Bhat, R., Wiermer, M., Stein, M., Landtag, J., Brandt, W., Rosahl, S., Scheel, D., Llorente, F., Molina, A., Parker, J., Somerville, S., and Schulze-Lefert, P. 2005. Pre- and postinvasion defenses both contribute to nonhost resistance in Arabidopsis. Science 310:1180-1183.

Lorrain, C., Marchal, C., Hacquard, S., Delaruelle, C., Pétrowski, J., Petre, B., Hecker, A., Frey, P., and Duplessis, S. 2018. The rust fungus Melampsora larici-populina expresses a conserved genetic program and distinct sets of secreted protein genes during infection of its two host plants, larch and poplar. Mol. Plant-Microbe Interact. 31:695-706.

Lowe, K., Wu, E., Wang, N., Hoerster, G., Hastings, C., Cho, M.-J., Scelonge, C., Lenderts, B., Chamberlin, M., Cushatt, J., Wang, L., Ryan, L., Khan, T., Chow-Yiu, J., Hua, W., Yu, M., Banh, J., Bao, Z., Brink, K., Igo, E., Rudrappa, B., Shamseer, P. M., Bruce, W., Newman, L., Shen, B., Zheng, P., Bidney, D., Falco, C., Register, J., Zhao, Z.-Y., Xu, D., Jones, T., and Gordon-Kamm, W. 2016. Morphogenic regulators Baby boom and Wuschel improve monocot transformation. Plant Cell 28: 1998-2015.

Lu, F., Wang, H., Wang, S., Jiang, W., Shan, C., Li, B., Yang, J., Zhang, S., and Sun, W. 2015. Enhancement of innate immune system in monocot rice by transferring the dicotyledonous elongation factor Tu receptor EFR. J. Integr. Plant Biol. 57:641-652.

Lu, M., Tang, X., and Zhou, J. M. 2001. Arabidopsis NHO1 is required for general resistance against Pseudomonas bacteria. Plant Cell 13: 437-447.

Lundberg, D. S., Lebeis, S. L., Paredes, S. H., Yourstone, S., Gehring, J., Malfatti, S., Tremblay, J., Engelbrektson, A., Kunin, V., Del Rio, T. G., Edgar, R. C., Eickhorst, T., Ley, R. E., Hugenholtz, P., Tringe, S. G., and Dangl, J. L. 2012. Defining the core Arabidopsis thaliana root microbiome. Nature 488:86-90.

Luo, M., Gilbert, B., and Ayliffe, M. 2016. Applications of CRISPR/Cas9 technology for targeted mutagenesis, gene replacement and stacking of genes in higher plants. Plant Cell Rep. 35:1439-1450.

Malcolm, G. M., Kuldau, G. A., Gugino, B. K., and Jiménez-Gasco, M. del M. 2013. Hidden host plant associations of soilborne fungal pathogens: An ecological perspective. Phytopathology 103:538-544.

Malinovsky, F. G., Fangel, J. U., and Willats, W. G. T. 2014. The role of the cell wall in plant immunity. Front. Plant Sci. 5:178.

Matsukawa, M., Shibata, Y., Ohtsu, M., Mizutani, A., Mori, H., Wang, P., Ojika, M., Kawakita, K., and Takemoto, D. 2013. Nicotiana benthamiana calreticulin $3 \mathrm{a}$ is required for the ethylene-mediated production of phytoalexins and disease resistance against oomycete pathogen Phytophthora infestans. Mol. Plant-Microbe Interact. 26:880-892.

Melotto, M., Underwood, W., Koczan, J., Nomura, K., and He, S. Y. 2006. Plant stomata function in innate immunity against bacterial invasion. Cell 126:969-980.

Melotto, M., Zhang, L., Oblessuc, P. R., and He, S. Y. 2017. Stomatal defense a decade later. Plant Physiol. 174:561-571.

Menardo, F., Praz, C. R., Wyder, S., Ben-David, R., Bourras, S., Matsumae, H., McNally, K. E., Parlange, F., Riba, A., Roffler, S., Schaefer, L. K., Shimizu, K. K., Valenti, L., Zbinden, H., Wicker, T., and Keller, B. 2016. Hybridization of powdery mildew strains gives rise to pathogens on novel agricultural crop species. Nat. Genet. 48:201-205.

Mendes, B. M. J., Cardoso, S. C., Boscariol-Camargo, R. L., Cruz, R. B., Mourão Filho, F. A. A., and Bergamin Filho, A. 2010. Reduction in susceptibility to Xanthomonas axonopodis pv. citri in transgenic Citrus sinensis expressing the rice Xa21 gene. Plant Pathol. 59:68-75.

Mercier, A., Carpentier, F., Duplaix, C., Auger, A., Pradier, J.-M., Viaud, M., Gladieux, P., and Walker, A.-S. 2019. The polyphagous plant pathogenic fungus Botrytis cinerea encompasses host-specialized and generalist populations. Environ. Microbiol. 21:4808-4821.

Morris, C. E., and Moury, B. 2019. Revisiting the concept of host range of plant pathogens. Annu. Rev. Phytopathol. 57:63-90. 
Navaud, O., Barbacci, A., Taylor, A., Clarkson, J. P., and Raffaele, S. 2018. Shifts in diversification rates and host jump frequencies shaped the diversity of host range among Sclerotiniaceae fungal plant pathogens. Mol. Ecol. 27:1309-1323.

Newton, A. C., and Crute, I. R. 1989. A consideration of the genetic control of species specificity in fungal plant pathogens and its relevance to a comprehension of the underlying mechanisms. Biol. Rev. 64:35-50.

Ngou, B. P. M., Ahn, H.-K., Ding, P., and Jones, J. D. G. 2020. Mutual potentiation of plant immunity by cell-surface and intracellular receptors. bioRxiv. doi:10.1101/2020.04.10.034173

Nieto, C., Rodríguez-Moreno, L., Rodríguez-Hernández, A. M., Aranda, M. A., and Truniger, V. 2011. Nicotiana benthamiana resistance to nonadapted Melon necrotic spot virus results from an incompatible interaction between virus RNA and translation initiation factor 4E. Plant J. 66:492-501.

Niks, R. E., and Marcel, T. C. 2009. Nonhost and basal resistance: How to explain specificity? New Phytol. 182:817-828.

Nürnberger, T., and Lipka, V. 2005. Non-host resistance in plants: New insights into an old phenomenon. Mol. Plant Pathol. 6:335-345.

Oh, S.-K., Young, C., Lee, M., Oliva, R., Bozkurt, T. O., Cano, L. M., Win, J., Bos, J. I. B., Liu, H.-Y., van Damme, M., Morgan, W., Choi, D., Van der Vossen, E. A. G., Vleeshouwers, V. G. A. A., and Kamoun, S. 2009. In planta expression screens of Phytophthora infestans RXLR effectors reveal diverse phenotypes, including activation of the Solanum bulbocastanum disease resistance protein Rpi-blb2. Plant Cell 21:2928-2947.

Peng, Y., van Wersch, R., and Zhang, Y. 2018. Convergent and divergent signaling in PAMP-triggered immunity and effector-triggered immunity. Mol. Plant-Microbe Interact. 31:403-409.

Pfeilmeier, S., George, J., Morel, A., Roy, S., Smoker, M., Stransfeld, L., Downie, J. A., Peeters, N., Malone, J. G., and Zipfel, C. 2019. Expression of the Arabidopsis thaliana immune receptor EFR in Medicago truncatula reduces infection by a root pathogenic bacterium, but not nitrogen-fixing rhizobial symbiosis. Plant Biotechnol. J. 17:569-579.

Rajaraman, J., Douchkov, D., Hensel, G., Stefanato, F. L., Gordon, A., Ereful, N., Caldararu, O. F., Petrescu, A.-J., Kumlehn, J., Boyd, L. A., and Schweizer, P. 2016. An LRR/malectin receptor-like kinase mediates resistance to non-adapted and adapted powdery mildew fungi in barley and wheat. Front. Plant Sci. 7:1836.

Riley, R., and Macer, R. C. F. 1966. The chromosomal distribution of the genetic resistance of rye to wheat pathogens. Can. J. Genet. Cytol. 8:640-653.

Rodriguez-Moreno, L., Song, Y., and Thomma, B. P. 2017. Transfer and engineering of immune receptors to improve recognition capacities in crops. Curr. Opin. Plant Biol. 38:42-49.

Romero, C. C. T., Vermeulen, J. P., Vels, A., Himmelbach, A., Mascher, M., and Niks, R. E. 2018. Mapping resistance to powdery mildew in barley reveals a large-effect nonhost resistance QTL. Theor. Appl. Genet. 131: 1031-1045.

Santini, A., Liebhold, A., Migliorini, D., and Woodward, S. 2018. Tracing the role of human civilization in the globalization of plant pathogens. ISME J. 12:647-652.

Schoonbeek, H.-J., Wang, H.-H., Stefanato, F. L., Craze, M., Bowden, S., Wallington, E., Zipfel, C., and Ridout, C. J. 2015. Arabidopsis EF-Tu receptor enhances bacterial disease resistance in transgenic wheat. New Phytol. 206:606-613.

Schreiber, C., Slusarenko, A. J., and Schaffrath, U. 2011. Organ identity and environmental conditions determine the effectiveness of nonhost resistance in the interaction between Arabidopsis thaliana and Magnaporthe oryzae. Mol. Plant Pathol. 12:397-402.

Schultink, A., Qi, T., Lee, A., Steinbrenner, A. D., and Staskawicz, B. 2017. Roq1 mediates recognition of the Xanthomonas and Pseudomonas effector proteins XopQ and HopQ1. Plant J. 92:787-795.

Schulze-Lefert, P., and Panstruga, R. 2011. A molecular evolutionary concept connecting nonhost resistance, pathogen host range, and pathogen speciation. Trends Plant Sci. 16:117-125.

Schwessinger, B., Bahar, O., Thomas, N., Holton, N., Nekrasov, V., Ruan, D., Canlas, P. E., Daudi, A., Petzold, C. J., Singan, V. R., Kuo, R., Chovatia, M., Daum, C., Heazlewood, J. L., Zipfel, C., Ronald, P. C., and Ronald, P. C. 2015. Transgenic expression of the dicotyledonous pattern recognition receptor EFR in rice leads to ligand-dependent activation of defense responses. PLoS Pathog. 11:e1004809.

Senthil-Kumar, M., Lee, H.-K., and Mysore, K. S. 2013. VIGS-mediated forward genetics screening for identification of genes involved in nonhost resistance. J. Vis. Exp. 78:e51033.

Senthil-Kumar, M., and Mysore, K. S. 2013. Nonhost resistance against bacterial pathogens: Retrospectives and prospects. Annu. Rev. Phytopathol. 51:407-427.

Sharifi, R., Lee, S.-M., and Ryu, C.-M. 2018. Microbe-induced plant volatiles. New Phytol. 220:684-691.
Sharma, M., and Bhatt, D. 2015. The circadian clock and defence signalling in plants. Mol. Plant Pathol. 16:210-218.

Sharma, R., Liang, Y., Lee, M. Y., Pidatala, V. R., Mortimer, J. C., and Scheller, H. V. 2020. Agrobacterium-mediated transient transformation of sorghum leaves for accelerating functional genomics and genome editing studies. BMC Res. Notes 13:116.

Shibata, Y., Kawakita, K., and Takemoto, D. 2011. SGT1 and HSP90 are essential for age-related non-host resistance of Nicotiana benthamiana against the oomycete pathogen Phytophthora infestans. Physiol. Mol. Plant Pathol. 75:120-128.

Shimada, C., Lipka, V., O’Connell, R., Okuno, T., Schulze-Lefert, P., and Takano, Y. 2006. Nonhost resistance in Arabidopsis-Colletotrichum interactions acts at the cell periphery and requires actin filament function. Mol. Plant-Microbe Interact. 19:270-279.

Sohn, K. H., Lei, R., Nemri, A., and Jones, J. D. G. 2007. The downy mildew effector proteins ATR1 and ATR13 promote disease susceptibility in Arabidopsis thaliana. Plant Cell 19:4077-4090.

Sohn, K. H., Saucet, S. B., Clarke, C. R., Vinatzer, B. A., O’Brien, H. E., Guttman, D. S., and Jones, J. D. G. 2012. HopAS1 recognition significantly contributes to Arabidopsis nonhost resistance to Pseudomonas syringae pathogens. New Phytol. 193:58-66.

Stam, R., Mantelin, S., McLellan, H., and Thilliez, G. 2014. The role of effectors in nonhost resistance to filamentous plant pathogens. Front. Plant Sci. 5:582.

Stein, M., Dittgen, J., Sánchez-Rodríguez, C., Hou, B. H., Molina, A., Schulze-Lefert, P., Lipka, V., and Somerville, S. 2006. Arabidopsis PEN3/PDR8, an ATP binding cassette transporter, contributes to nonhost resistance to inappropriate pathogens that enter by direct penetration. Plant Cell 18:731-746.

Stergiopoulos, I., and Gordon, T. R. 2014. Cryptic fungal infections: The hidden agenda of plant pathogens. Front. Plant Sci. 5:506.

Strugala, R., Delventhal, R., and Schaffrath, U. 2015. An organ-specific view on non-host resistance. Front. Plant Sci. 6:526.

Stukenbrock, E. H. 2016. The role of hybridization in the evolution and emergence of new fungal plant pathogens. Phytopathology 106:104-112.

Sumit, R., Sahu, B. B., Xu, M., Sandhu, D., and Bhattacharyya, M. K. 2012. Arabidopsis nonhost resistance gene PSS1 confers immunity against an oomycete and a fungal pathogen but not a bacterial pathogen that cause diseases in soybean. BMC Plant Biol. 12:87.

Tatineni, S., Robertson, C. J., Garnsey, S. M., and Dawson, W. O. 2011. A plant virus evolved by acquiring multiple nonconserved genes to extend its host range. Proc. Natl. Acad. Sci. U.S.A. 108:17366-17371.

Thines, M. 2019. An evolutionary framework for host shifts-Jumping ships for survival. New Phytol. 224:605-617.

Thordal-Christensen, H. 2003. Fresh insights into processes of nonhost resistance. Curr. Opin. Plant Biol. 6:351-357.

Thresh, J. M. 1982. Cropping practices and virus spread. Annu. Rev. Phytopathol. 20:193-216.

Toruño, T. Y., Stergiopoulos, I., and Coaker, G. 2016. Plant-pathogen effectors: Cellular probes interfering with plant defenses in spatial and temporal manners. Annu. Rev. Phytopathol. 54:419-441.

Tosa, Y. 1989. Evidence on wheat for gene-for-gene relationship between formae speciales of Erysiphe graminis and genera of gramineous plants. Genome 32:918-924.

Tosa, Y. 1992. A model for the evolution of the formae speciales and races. Phytopathology 82:728-730.

Tripathi, J. N., Lorenzen, J., Bahar, O., Ronald, P., and Tripathi, L. 2014. Transgenic expression of the rice Xa21 pattern-recognition receptor in banana (Musa sp.) confers resistance to Xanthomonas campestris pv. musacearum. Plant Biotechnol. J. 12:663-673.

Tsuda, K., and Somssich, I. E. 2015. Transcriptional networks in plant immunity. New Phytol. 206:932-947.

Underwood, W. 2012. The plant cell wall: A dynamic barrier against pathogen invasion. Front. Plant Sci. 3:85.

Uppalapati, S. R., Ishiga, Y., Doraiswamy, V., Bedair, M., Mittal, S., Chen, J., Nakashima, J., Tang, Y., Tadege, M., Ratet, P., Chen, R., Schultheiss, H., and Mysore, K. S. 2012. Loss of abaxial leaf epicuticular wax in Medicago truncatula irg1/palml mutants results in reduced spore differentiation of anthracnose and nonhost rust pathogens. Plant Cell 24:353-370.

Van de Weyer, A.-L., Monteiro, F., Furzer, O. J., Nishimura, M. T., Cevik, V., Witek, K., Jones, J. D. G., Dangl, J. L., Weigel, D., and Bemm, F. 2019. A species-wide inventory of NLR genes and alleles in Arabidopsis thaliana. Cell 178:1260-1272.e14.

VanEtten, H. D., Mansfield, J. W., Bailey, J. A., and Farmer, E. E. 1994. Two classes of plant antibiotics: Phytoalexins versus phytoanticipins. Plant Cell 6:1191-1192.

Vannier, N., Agler, M., and Hacquard, S. 2019. Microbiota-mediated disease resistance in plants. PLoS Pathog. 15:e1007740. 
van Schie, C. C. N., and Takken, F. L. W. 2014. Susceptibility genes 101: How to be a good host. Annu. Rev. Phytopathol. 52:551-581.

van Wersch, S., Tian, L., Hoy, R., and Li, X. 2020. Plant NLRs: The whistleblowers of plant immunity. Plant Commun. 1:100016.

Vega-Arreguín, J. C., Shimada-Beltrán, H., Sevillano-Serrano, J., and Moffett, P. 2017. Non-host plant resistance against Phytophthora capsici is mediated in part by members of the $I 2 R$ gene family in Nicotiana spp. Front. Plant Sci. 8:205.

Velásquez, A. C., Castroverde, C. D. M., and He, S. Y. 2018. Plant-pathogen warfare under changing climate conditions. Curr. Biol. 28:R619-R634.

Venard, C., and Vaillancourt, L. 2007. Penetration and colonization of unwounded maize tissues by the maize anthracnose pathogen Colletotrichum graminicola and the related nonpathogen $C$. sublineolum. Mycologia 99:368-377.

Vleeshouwers, V. G. A. A., Rietman, H., Krenek, P., Champouret, N., Young, C., Oh, S.-K., Wang, M., Bouwmeester, K., Vosman, B., Visser, R. G. F., Jacobsen, E., Govers, F., Kamoun, S., and Van der Vossen, E. A. G. 2008. Effector genomics accelerates discovery and functional profiling of potato disease resistance and phytophthora infestans avirulence genes. PLoS One 3:e2875.

Vleeshouwers, V. G. A. A., van Dooijeweert, W., Govers, F., Kamoun, S., and Colon, L. T. 2000. The hypersensitive response is associated with host and nonhost resistance to Phytophthora infestans. Planta 210:853-864.

Wagner, M. R., Lundberg, D. S., Del Rio, T. G., Tringe, S. G., Dangl, J. L., and Mitchell-Olds, T. 2016. Host genotype and age shape the leaf and root microbiomes of a wild perennial plant. Nat. Commun. 7:12151.

Wang, B., Sumit, R., Sahu, B. B., Ngaki, M. N., Srivastava, S. K., Yang, Y., Swaminathan, S., and Bhattacharyya, M. K. 2018. Arabidopsis novel glycine-rich plasma membrane PSS1 protein enhances disease resistance in transgenic soybean plants. Plant Physiol. 176:865-878.

Wang, Y., Subedi, S., de Vries, H., Doornenbal, P., Vels, A., Hensel, G., Kumlehn, J., Johnston, P. A., Qi, X., Blilou, I., Niks, R. E., and Krattinger, S. G. 2019. Orthologous receptor kinases quantitatively affect the host status of barley to leaf rust fungi. Nat. Plants 5:1129-1135.

Wei, C.-F., Kvitko, B. H., Shimizu, R., Crabill, E., Alfano, J. R., Lin, N.-C., Martin, G. B., Huang, H.-C., and Collmer, A. 2007. A Pseudomonas syringae pv. tomato DC3000 mutant lacking the type III effector HopQ11 is able to cause disease in the model plant Nicotiana benthamiana. Plant J. 51:32-46.

Wei, H.-L., Chakravarthy, S., Mathieu, J., Helmann, T. C., Stodghill, P., Swingle, B., Martin, G. B., and Collmer, A. 2015. Pseudomonas syringae pv. tomato DC3000 type III secretion effector polymutants reveal an interplay between HopAD1 and AvrPtoB. Cell Host Microbe 17:752-762.

Wei, H.-L., Zhang, W., and Collmer, A. 2018. Modular study of the type III effector repertoire in Pseudomonas syringae pv. tomato DC3000 reveals a matrix of effector interplay in pathogenesis. Cell Rep. 23:1630-1638.

Weidenbach, D., Jansen, M., Franke, R. B., Hensel, G., Weissgerber, W., Ulferts, S., Jansen, I., Schreiber, L., Korzun, V., Pontzen, R., Kumlehn, J., Pillen, K., and Schaffrath, U. 2014. Evolutionary conserved function of barley and Arabidopsis 3-KETOACYL-CoA SYNTHASES in providing wax signals for germination of powdery mildew fungi. Plant Physiol. 166:1621-1633.

Wheeler, D. L., Dung, J. K. S., and Johnson, D. A. 2019. From pathogen to endophyte: An endophytic population of Verticillium dahliae evolved from a sympatric pathogenic population. New Phytol. 222:497-510.

Witek, K., Jupe, F., Witek, A. I., Baker, D., Clark, M. D., and Jones, J. D. G. 2016. Accelerated cloning of a potato late blight-resistance gene using RenSeq and SMRT sequencing. Nat. Biotechnol. 34:656-660.

Wulff, B. B. H., Horvath, D. M., and Ward, E. R. 2011. Improving immunity in crops: New tactics in an old game. Curr. Opin. Plant Biol. 14:468-476.

Wulff, B. B. H., and Moscou, M. J. 2014. Strategies for transferring resistance into wheat: From wide crosses to GM cassettes. Front. Plant Sci. 5:692.

Yaegashi, H. 1978. Inheritance of pathogenicity in crossess of Pyricularia isolates from weeping lovegrass and finger millet. Jpn. J. Phytopathol. 44:626-632.

Yamauchi, Y., Makihara, M., and Ishikawa, A. 2017. Leaf age and time of inoculation contribute to nonhost resistance to Pyricularia oryzae in Arabidopsis thaliana. Plant Biotechnol Tokyo 34:207-210.

Yamaura, S., Yamauchi, Y., Makihara, M., Yamashino, T., and Ishikawa, A. 2020. CCA1 and LHY contribute to nonhost resistance to Pyricularia oryzae (syn. Magnaporthe oryzae) in Arabidopsis thaliana. Biosci. Biotechnol. Biochem. 84:76-84.

Yoshida, K., Schuenemann, V. J., Cano, L. M., Pais, M., Mishra, B., Sharma, R., Lanz, C., Martin, F. N., Kamoun, S., Krause, J., Thines, M., Weigel, D., and Burbano, H. A. 2013. The rise and fall of the Phytophthora infestans lineage that triggered the Irish potato famine. eLife 2:e00731.

Yu, Z., Shen, K., Newcombe, G., Fan, J., and Chen, Q. 2019. Leaf cuticle can contribute to non-host resistance to poplar leaf rust. Forests 10:870

Yuan, M., Jiang, Z., Bi, G., Nomura, K., Liu, M., He, S. Y., Zhou, J.-M., and Xin, X.-F. 2020. Pattern-recognition receptors are required for NLRmediated plant immunity. bioRxiv. doi:10.1101/2020.04.10.031294

Yun, B. W., Atkinson, H. A., Gaborit, C., Greenland, A., Read, N. D., Pallas, J. A., and Loake, G. J. 2003. Loss of actin cytoskeletal function and EDS1 activity, in combination, severely compromises non-host resistance in Arabidopsis against wheat powdery mildew. Plant J. 34: 768-777.

Zhang, N. W., Lindhout, P., Niks, R. E., and Jeuken, M. J. W. 2009. Genetic dissection of Lactuca saligna nonhost resistance to downy mildew at various lettuce developmental stages. Plant Pathol. 58:923-932.

Zhao, B., Lin, X., Poland, J., Trick, H., Leach, J., and Hulbert, S. 2005. A maize resistance gene functions against bacterial streak disease in rice. Proc. Natl. Acad. Sci. U.S.A. 102:15383-15388.

Zhao, J., Yang, Y., Yang, D., Cheng, Y., Jiao, M., Zhan, G., Zhang, H., Wang, J., Zhou, K., Huang, L., and Kang, Z. 2016. Characterization and genetic analysis of rice mutant crrl exhibiting compromised non-host resistance to Puccinia striiformis f. sp. tritici (Pst). Front. Plant Sci. 7: 1822. 